\title{
The long view
}

\author{
Dawn S. Hui, MD, and Richard Lee, MD, MBA
}

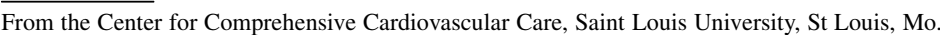 \\ Disclosures: Authors have nothing to disclose with regard to commercial support. \\ Received for publication March 23, 2017; accepted for publication March 23, 2017; available ahead of print April \\ $27,2017$. \\ Address for reprints: Richard Lee, MD, MBA, 3635 Vista Ave, DT 13th Floor, St Louis, MO 63110 (E-mail: \\ rlee@slu.edu). \\ J Thorac Cardiovasc Surg 2017;154:845-6 \\ $0022-5223 / \$ 36.00$ \\ Copyright (C) 2017 Published by Elsevier Inc. on behalf of The American Association for Thoracic Surgery \\ http://dx.doi.org/10.1016/j.jtcvs.2017.03.110
}

The distinction between rheumatic and degenerative mitral valve disease is evident at numerous levels, not only with respect to the pathophysiologic changes affecting the valve but in the disparate characteristics of the populations affected, including age of presentation, geographic and socioeconomic distribution, and gender. Because of this, there are few studies comparing surgical outcomes for these 2 entities, although more recent enthusiasm and success with repair techniques for rheumatic mitral disease is starting to change that landscape. ${ }^{1}$

In this issue of the Journal, Labin and colleagues ${ }^{2}$ present an institutional study of patients with degenerative and rheumatic mitral disease undergoing the Cox maze IV procedure for atrial fibrillation (AF) concomitantly with mitral valve surgery. On the basis of multivariate logistic regression analysis, they concluded that the long-term efficacy of the Cox maze IV procedure was similar between the disease groups. This is a valuable study, because there are few others examining this question; however, the question is whether the best analysis or comparison was done. As is to be expected, there were significant differences between the groups across nearly all the preoperative variables; also to be expected, mitral repair rates differed significantly $(9 \%$ in rheumatic disease, $82 \%$ in degenerative disease). This of course brings to mind the timeworn phrase "comparing apples to oranges." The concept, though bordering on tiresome, is important to keep in mind; as Blackstone ${ }^{3}$ stated, this question is "not academic; it can affect the way we as physicians learn to treat our patients from studies of clinical experience." The limitation is of course, sample size. Blackstone ${ }^{3}$ also opined that matching techniques are appropriate "even for modest-sized data sets." Yet the impact of matching on sample size is significant; in our previous study of cardiac surgery patients with and without preoperative AF, propensity score matching reduced the number of patients for analysis by $77 \%$ (from 3262 to 744 ). ${ }^{4}$

Because of this limitation, it may be instructive to look back at other studies on rheumatic patients undergoing $\mathrm{AF}$ ablation. In particular, the series of patients undergoing the Cox maze III procedure reported on by Kim and

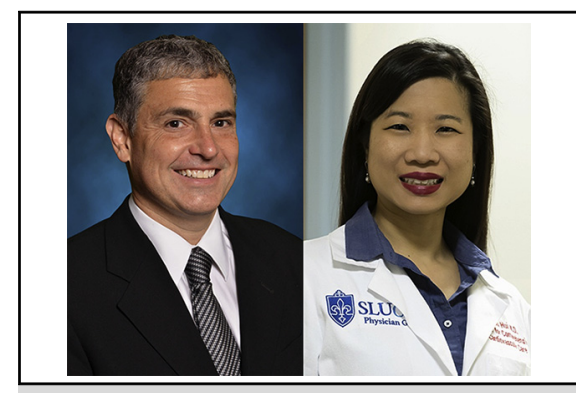

Richard Lee, MD, MBA (left), and Dawn S. Hui, MD (right).

\section{Central Message}

Maximizing efficacy of the Cox maze procedure for atrial fibrillation should be considered for patients with rheumatic mitral disease, just as for those with other etiologies.

See Article page 835 .

associates $^{5}$ provides longer-term outcomes for comparison. $^{5}$ The midterm results of Labin and colleagues ${ }^{2}$ compare favorably, with nearly equivalent 1-, 3-, and 5year outcomes. In fact, their results are even more impressive when considering the fact that the older Cox maze III study did not have current rhythm monitoring modalities available and examined outcomes with electrocardiography only; thus it may have been more likely to overestimate success. What bears noting is that in the study of Kim and associates, ${ }^{5}$ the long-term success rate continued to decline, from $71 \%$ at 5 years to $63 \%$ at 7 years. Given that patients with rheumatic disease tend to be younger, the question of longer-term success is important. Although Labin and colleagues $^{2}$ found a posterior box lesion to be a significant factor favoring success, other surgical considerations, such as left atrial reduction, were not described. A biatrial reduction plasty, described by Romano and colleagues ${ }^{6}$ for predicted "low-success" AF patients, had excellent efficacy in those with long preoperative AF duration and large left atria. Lee and associates ${ }^{7}$ described a modification of the cut-and-sew maze procedure that included an element of left atrial reduction. Whereas their short-term results were similar between the rheumatic and degenerative groups, ${ }^{7,8}$ 4.4-year follow-up showed significantly greater progressive loss of left atrial function in those with rheumatic disease. ${ }^{9}$ An aggressive approach with biatrial reduction plasty thus may provide additional benefit. Finally, if there is a trend toward repair of rheumatic mitral valves, the interaction of long-term AF ablation success 
with repair durability and survival needs to be considered. In a series examining 10-year outcomes of mitral repair for rheumatic disease, Kim and coworkers ${ }^{10}$ demonstrated postoperative late AF to be the only independent predictor of decreased event-free survival (hazard ratio, 3.18; $95 \%$ confidence interval, 1.27-7.67; $P=.014$ ). Failure to ablate $\mathrm{AF}$ at the time of mitral repair independently predicted mitral dysfunction.

We therefore commend Labin and colleagues $^{2}$ for bringing to attention the treatment of this challenging population. Just as the needle seems to be moving toward repair when possible for these patients, the long view toward achieving even better durability of repair, permanent $\mathrm{AF}$ ablation, and survival may be the new perspective.

\section{References}

1. Dillon J, Yakub MA, Kong PK, Ramli MF, Jaffar N, Gaffar IF. Comparative long-term results of mitral valve repair in adults with chronic rheumatic disease and degenerative disease: is repair for "burnt-out" rheumatic disease still inferior to repair for degenerative disease in the current era? J Thorac Cardiovasc Surg. 2015;149:771-7.

2. Labin JE, Haque N, Sinn LA, Schuessler RB, Moon MR, Maniar HS, et al. The Cox-Maze IV procedure for atrial fibrillation is equally efficacious in patients with rheumatic and degenerative mitral valve disease. J Thorac Cardiovasc Surg. 2017; 154:835-44.

3. Blackstone EH. Comparing apples and oranges. J Thorac Cardiovasc Surg. 2002; 123:8-15.

4. Lee R, McCarthy P, Wang EC, Vaduganathan M, Kruse J, Malaisrie SC, et al. Midterm survival in patients treated for atrial fibrillation: a propensity-matched comparison to patients without a history of atrial fibrillation. J Thorac Cardiovasc Surg. 2012;143:1341-51; discussion 1350-1.

5. Kim KC, Chow KR, Kim YJ, Sohn DW, Kim KB. Long-term results of the Cox-Maze III procedure for persistent atrial fibrillation associated with rheumatic mitral valve disease: 10-year experience. Eur J Cardiothorac Surg. 2007;31:261-6.

6. Romano MA, Bach DS, Pagani FD, Prager RL, Deeb M, Bolling SF. Atrial reduction plasty Cox maze procedure: extended indications for atrial fibrillation surgery. Ann Thorac Surg. 2004;77:1282-7; discussion 1287.

7. Lee JW, Choo SJ, Kim KI, Song JK, Kang DH, Song JM, et al. Atrial fibrillation surgery simplified with cryoablation to improve left atrial function. Ann Thorac Surg. 2001;72:1479-83.

8. Lee JW, Park NH, Choo SJ, Jo MS, Song H, Song MG. Surgical outcome of the maze procedure for atrial fibrillation in mitral valve disease: rheumatic versus degenerative. Ann Thorac Surg. 2003;75:57-61; discussion 61.

9. Kim HW, Moon MH, Jo KH, Song H, Lee JW. Left atrial and left ventricular diastolic function after the MAZE procedure for atrial fibrillation in mitral valve disease: degenerative versus rheumatic. Indian J Surg. 2015;77:7-15.

10. Kim GS, Lee CH, Kim JB, Jung SH, Choo SJ, Chung $\mathrm{CH}$, et al. Echocardiographic evaluation of mitral durability following valve repair in rheumatic mitral valve disease: impact of Maze procedure. J Thorac Cardiovasc Surg. 2014;147:247-53. 